\title{
Anti-CD20 Monoclonal Antibody TL011
}

National Cancer Institute

\section{Source}

National Cancer Institute. Anti-CD20 Monoclonal Antibody TL011. NCI Thesaurus. Code C94206.

A monoclonal antibody directed ag ainst human CD20 with potential antineoplastic activity. Anti-CD20 monoclonal antibody TL011 specifically binds to the B cell-specific cell surface antigen CD20 antigen (MS4A1; membrane-spanning 4-domains, subfamily A, member 1 ), thereby potentially trigg ering an immune response against CD20-positive $B$ cells, leading to B cell apoptosis. CD20 is a non-glycosylated cell surface phosphoprotein that is exclusively expressed on B cells during most stages of B cell development and is often overexpressed in B-cell malignancies. 